\title{
The one, the true, the good... or not: Badiou, Agamben, and atheistic transcendentality
}

\author{
King-Ho Leung ${ }^{1}$
}

Accepted: 2 December 2020 / Published online: 13 January 2021

(c) The Author(s) 2021

\begin{abstract}
This article offers a reading of the "transcendental" character of Alain Badiou's and Giorgio Agamben's ontologies. While neither Badiou nor Agamben are "transcendental" philosophers in the Kantian sense, this article argues that their respective projects of ontology both recover aspects of the "classical" conception of the transcendentals. Not unlike how pre-modern philosophers conceived of oneness, truth and goodness as transcendental properties of all things, both Badiou's and Agamben's ontologies present various structures which can be universally predicated of all being. However, as opposed to the essentialist or even theological tendencies of traditional metaphysics, Badiou's and Agamben's ontologies are committedly "inessential" and atheistic at their very core. By replacing the divine names of the one, the true and the good in traditional metaphysics with a new yet quasi-classical transcendental notion of "the void" as a universal predicate of all beings, Badiou's and Agamben's works may be regarded as projects that go beyond both the pre-Kantian "theological" and the post-Kantian "subjective" conceptions of transcendental philosophy, thereby marking a new development in the history of western metaphysics.
\end{abstract}

Keywords Badiou $\cdot$ Agamben $\cdot$ Transcendental $\cdot$ Ontology $\cdot$ Metaphysics $\cdot$ Atheism

By his very own description, Alain Badiou's philosophy is "resolutely classical" in the sense that it "does not submit to the critical injunctions of Kant." For Badiou, to be a "classical" philosopher is to see "the Kantian indictment of metaphysics as null and void" and to hold that it is "possible to think Being" once again. ${ }^{1}$ Such an attempt to "think Being" is also found in the works of Giorgio Agamben, who shares with Badiou a certain hostility towards Kant's critical injunctions on ontology. ${ }^{2}$

\footnotetext{
1 Badiou (2000, p. 45).

2 See, for instance, Agamben (2015, p. 111; 2013, pp. 121-122).

King-Ho Leung

k1322@st-andrews.ac.uk

1 St Mary’s College, University of St Andrews, South Street, St Andrews KY16 9JU, UK
} 
According to Agamben, it was with Kant's re-definition of "the transcendental" that philosophy ceased to "think Being": "when with Kant the transcendental ceases to be what thought must get to the bottom of and instead becomes the stronghold in which it takes refuge, then philosophy loses its relation with Being." ${ }^{3}$ For Agamben, as for Badiou, Kant's "transcendental" turn marks a devastating turning point in the trajectory of western philosophy or even the so-called history of Being.

This article offers an examination of the role of the "transcendental" in the works of Badiou and Agamben. Although Badiou and Agamben are by no means "transcendental" philosophers in the Kantian sense, this article argues that their respective projects of ontology both recover a pre-modern or indeed pre-Kantian classical sense of "transcendentality" as the essential properties of being which can be universally found in any and every particular thing insofar as it exists. ${ }^{4}$ While this pre-modern "classical" conception of transcendentality is often found in explicit discussions of the Scholastic transcendentals of the one, the true, and the good across Agamben's various works, a classical conception of the transcendental can also be implicitly found in Badiou's mathematical ontology which is consciously developed in opposition to Kant's transcendental idealism. But although both Badiou's and Agamben's ontologies have "transcendental" notions which bear remarkable resemblances to the classical transcendentals, as opposed to the "essentialist" character of classical metaphysics, both of their projects are attempts to develop an "inessential" ontology that does not prescribe or impose any essence or nature onto things themselves: For both Badiou and Agamben, the identity and quality of beings are not defined or measured by some transcendent source of essence.

While there have been some insightful studies on Badiou's and Agamben's complicated relationship with Kant's transcendental idealism in the existing philosophical literature, ${ }^{5}$ there has been little discussion of how their ontologies relate to the "classical" transcendentals as expounded in pre-modern metaphysics. ${ }^{6}$ By examining Badiou's and Agamben's projects with reference to the pre-modern "classical" conception of transcendentality, this article seeks to offer a new perspective not only for the interpretation of Badiou's and Agamben's influential work, but also for our understanding of the place of "transcendentality" in contemporary philosophy and its relation to the developments in the history of western metaphysics more broadly. This article begins with a brief overview of the pre-modern classical conception of transcendentality and its differences from Kant's. This is followed by two sections

\footnotetext{
3 Agamben (2015, p. 271, cf. p. 113).

4 This pre-Kantian conception is, however, not to be confused with Adrian Johnston's (post-Kantian) notion of the "meta-transcendental" that is "the ontogenetic conditions of possibility for the genesis of the transcendental, cogito-like subject (i.e., the meta-transcendental level underpinning transcendental subjectivity" (Johnston 2008b, p. xxv).

5 See Johnston (2008a; 2013, pp. 108-128); Brophy (2019).

6 While the Scholastic conception of the transcendentals is technically a "medieval" as opposed to "classical" (qua ancient) formulation, following Badiou's non-Kantian definition of "classical" philosophy, Kant's description of medieval Scholasticism as "transcendental philosophy of the ancients," and the Scholastic tradition's broad adherence to Aristotle's ancient- "classical"-account of the transcendental character of "oneness" (Metaphysics X.1052a-1059a), this article will simply refer to the medieval Scholastic conception of transcendentality as "classical."
} 
which respectively examine the "transcendental" character of Badiou's and Agamben's early and later works. After this, by way of comparing and contrasting Badiou's and Agamben's ontologies with previous versions of transcendental philosophy, the article concludes by highlighting how Badiou's and Agamben's quasi-classical conceptions of "atheistic transcendentality" can contribute to our understanding of the unique characteristics of contemporary continental philosophy in relation to the wider currents in the history of metaphysics.

\section{Kant and the "transcendental philosophy of the ancients"}

In contemporary philosophy, the notion of the "transcendental" is often associated with Kant's influential account of the transcendental ideality of time and space as conditions for human cognition. However, in the Critique of Pure Reason, Kant actually refers to his own conception of "transcendental philosophy" as an alternative to an older "transcendental philosophy of the ancients."7 As opposed to Kant's "modern" account philosophy of the "transcendental" which is "occupied not so much with objects as with our mode of knowledge of objects," the older "transcendental philosophy of the ancients" is concerned with the essential properties of things themselves. ${ }^{8}$ As Kant notes in the first Critique, this "older" transcendental philosophy is most famously expounded in the Scholastic proposition "quodlibet ens est unum, verum, bonum"- "every being is one, true, good." 9 According to this medieval thesis, the three terms of oneness, truth, and goodness are known as "transcendentals" (transcendentalia), which are "common notions" (communissima) that are properties of all things: They are called "transcendentals" because they "transcend" the Aristotelian categories in terms of their universality. Insofar as "every being is one, true, good," the notions of "oneness," "truth" and "goodness" are said to be coextensive with "Being" itself. ${ }^{10}$

Unlike other predicates or adjectives such as "angry," "red" or "smelly," each and every being can be said to be "one," "true," and "good." While it would be odd to say that a chair is "angry," that a number is "red," or that a sentence is "smelly," all of these things could be predicated with the classical transcendentals. Everything can be said to be "one" insofar as it is one thing or indeed a unit with some level of unity or oneness (every chair is one chair, every number is one number, every sentence

\footnotetext{
7 Kant (1929, p. 118 [B113]).

8 Ibid., p. 59 [B25], emphasis added.

9 Ibid., p. 118 [B113].

${ }^{10}$ This present discussion is obviously an extremely brief and simplified summary of a rich and complex tradition. For an in-depth and important study of the development of the medieval "classical" conception of transcendentality, see Aertsen (2012). While "Being" is sometimes listed among the transcendentals, partly due to the complicated controversies surrounding Kant's (1929, p. 504 [A598/B626]) assertion that "Being is not a real predicate" and Heidegger's critique of classical metaphysics as "onto-theology," instead of treating "Being" as a transcendental, this article focuses on "one," "true," and "good" as the chief transcendentals, which Jan Aertsen (2012, p. 663) describes as "the notions on which all agree" are transcendentals. For a discussion of "Being" as a transcendental, see Aertsen (1996, pp. 159-200).
} 
is one sentence). Likewise, according to the "classical" medieval outlook, even if things are not fully or "actually" good, everything has the potency to be good. Thus, everything can be predicated with "goodness" ("that is a good chair," "that is a good sentence," "that is a good number"). In a similar way, all things can be said to be "true"—or, so to speak, "truthful" ("that is a true chair," "a true sentence," "a true number"): There is some level of truth in all things insofar as they ("truly") exist and are intelligible - that they contain some sense of "truth." According to Scholastic metaphysics, the oneness, truth, and goodness we find in each and every being in the world are reflections of God's divine perfections: For God is the original and exemplary definition of oneness, truth and goodness - the transcendent measure by which we measure the oneness, truth and goodness of all created things. For Scholastic thinkers such as Thomas Aquinas, created things can be said to be one, good, or true only by virtue of their participation in God's divine perfections-or what are sometimes called the "divine names" —of Oneness, Truth, and Goodness. ${ }^{11}$

However, according to Kant, the Scholastic "transcendental predicates of things are, in fact, nothing but logical requirements and criteria of all knowledge of things in general." 12 As opposed to being "taken as material, as belonging to the possibility of things themselves," the ancient and medieval notions of unum, verum, bonum are merely "the criterion of the possibility of a concept" and "not of its object."13 Thus, Kant argues that classical metaphysics "incautiously" mistakes our "criteria of thought" for "properties of things in themselves." ${ }^{14}$ With this shift of focus from the property of things themselves to the mode of knowledge of things, Kant's famous "Copernican revolution" is paralleled with a redefinition of "transcendental philosophy" which became one of the defining concepts of modern thought. ${ }^{15}$ However, as we see in the following sections, Kant's revolutionary "Copernican" turn to the transcendental subject is questioned and challenged by a number of contemporary continental philosophers such as Alain Badiou and Giorgio Agamben. As opposed to being concerned with the conditions and limits of human knowledge, Badiou and Agamben not only consciously adapt notably non-Kantian philosophical approaches as to "think Being," their respective projects can moreover be seen as works which recast a "classical" sense of the transcendentals as common notions or indeed dimensions of Being itself - in some sense, returning to a mode of philosophising that Kant would associate with the "transcendental philosophy of the ancients."

\footnotetext{
11 Aertsen (2012, pp. 674-75); see also Aertsen (1996).

12 Kant (1929, p. 118 [B113-114]).

13 Ibid., p. 119 [B115].

14 Ibid., p. 118 [B114].

15 Cf. Honnefelder (2003).
} 


\section{Alain Badiou}

\subsection{Earlier Badiou: mathematical ontology}

While one may characterise the turn from medieval to modern philosophy in terms of a shift from the Scholastic definition of the "transcendental" as the ontological structure in which entities exist to Kant's definition as the epistemological conditions for our mode of cognition of things, ${ }^{16}$ for Badiou, the turn to modernity is marked by a change in the ontological status of "the One":

Modernity is defined by the fact that the One is not... that "God is dead"... for we moderns, the Multiple-without-One is the last word on being qua being. Now the thought of the pure multiple, of the multiple considered in itself, without consideration of what it is the multiple of, is called: "mathematical set theory." Therefore every major concept of this theory can be understood as a concept of modern ontology. ${ }^{17}$

In Badiou's view, to ontologically posit that "the One is not" is to say that God is dead, and to truly move ontological inquiry away from its historic theological captivity - to move beyond so-called onto-theology. ${ }^{18}$ As Badiou puts it:

There is no God. Which also means the One is not. The multiple "withoutone"- - every multiple being in its turn nothing other than a multiple of multiples - is the law of being. The only stopping point is the void. ${ }^{19}$

All things - all beings_-are multiples. For Badiou, multiples cannot be broken down or divided into ones, but only into further multiples: "The multiple is only ever composed of multiples. Every multiple is a multiple of multiples."20

Such an account of multiples consisting of further multiples-of the multiple that is "without-One" - is something that Badiou finds in modern "mathematical set theory": "Any multiple is intrinsically multiple of multiples: this is what set theory deploys." 21 It is for this reason that Badiou famously identifies mathematics - and specifically Cantorian set theory-as ontology itself in Being and Event (1988). This understanding of mathematics as ontology provides Badiou with a way to overcome the (onto-)theological focus on the One:

\footnotetext{
16 See, for example, Milbank (2014, pp. 30-31, 38-41).

17 Badiou (2008, p. 65).

18 Whereas Heidegger is worried that ontotheology thinks of the Being of beings as $a$ being, $a$ thing or indeed one thing (namely God), Badiou's ontological approach is to simply get rid of the idea of Oneness altogether to avoid the pitfalls of ontotheology. See Badiou (2004, pp. 39-48, especially p. 41).

19 Badiou (2001, p. 25).

20 Badiou (2004, p. 42); see also Badiou (2005, p. 57).

21 Badiou (2005, p. 45).
} 
By initiating a thinking in which the infinite is irrevocably separated from every instance of the One, mathematics has, in its own domain, successfully consummated the death of God. ${ }^{22}$

For Badiou, the most distinctive and profound ontological insight of set theory is that things (as sets) are not reducible to the one, but to zero or the "not"- the "stopping point" which Badiou calls "the void." ${ }^{23}$ Badiou notes: "Everything can potentially be reduced to a multiple without quality, made of the void alone." ${ }^{4}$

Drawing on von Neumann's set-theoretical formulation of ordinal numbers, Badiou speaks of the empty set—denoted as "0" or " $\varnothing "$ (what Badiou calls "the void") — as "the inaugural point of being." 25 All subsequent numbers or "successor ordinals" after 0 - such as 1, 2, 3, 4, and so on-can be formulated set-theoretically in terms of the empty set, i.e. in terms of the number 0 or $\varnothing$ :

$$
\begin{array}{ll}
0 & =\emptyset \\
1=\{0\} & =\{\emptyset\} \\
2=\{0,1\} & =\{\emptyset,\{\emptyset\}\} \\
3=\{0,1,2\} & =\{\emptyset,\{\emptyset\},\{\emptyset,\{\emptyset\}\}\} \\
4=\{0,1,2,3\} & =\{\emptyset,\{\emptyset\},\{\emptyset,\{\emptyset\}\},\{\emptyset,\{\emptyset\},\{\emptyset,\{\emptyset\}\}\}\}
\end{array}
$$

While it is not our main purpose to explicate Badiou's (admittedly contested) use of mathematics here, this brief presentation of his account of the composition of ordinal numbers can highlight two key features of Badiou's set-theoretical ontology. ${ }^{26}$

First, understood as a set, the number 1 is denoted by " $\{0\}$ " or " $\{\varnothing\}$ " (which is to be distinguished from the number zero which is an empty set represented by " $\varnothing "$ " [without the braces to denote the set]): number 1 is a set that is composed by the number 0 or $\varnothing$, a set that contains the number zero as an element. ${ }^{27}$ It is in this sense that the one may be said to be reducible to zero or the void: All things are fundamentally reducible not to the one but the void- "the only stopping point." To the extent that all numbers can be regarded as sets, they may be described as being "composed of the void." 28 Second, given that every "one" always already includes the void-that every $\{\varnothing\}$ includes $\varnothing$, and that all things (as sets) are ultimately composed of the void, the void is accordingly intrinsically included in all numbers and indeed in all sets, i.e. in all beings. As Badiou puts it:

The void is a subset of any set: it is universally included... [This] testifies to the omnipresence of the void. It reveals the errancy of the void in all presenta-

\footnotetext{
22 Badiou (2004, p. 36).

23 Badiou (2001, p. 25).

24 Badiou (2008, p. 131).

25 Ibid., p. 84.

${ }^{26}$ For some critiques of Badiou's use of set theory, see Johnston (2008a); Nirenberg and Nirenberg (2011); Gabriel (2015, pp. 116-131). On von Neumann's theory and the definition of natural numbers, see Fraenkel, Bar-Hillel and Levy (1973, pp. 91-95).

27 Badiou (2008, pp. 63-65, 95).

28 Ibid., pp. 77, 84.
} 
tion: the void, to which nothing belongs, is by this very fact included in everything. ${ }^{29}$

By attributing "omnipresence" to the void, one might wonder whether there is still a certain "theological" character to Badiou's set-theoretical ontology. But for Badiou, this is not an "omnipresence" of some transcendent divine figure, but rather an omnipresent declaration of an absence or "lack": "the void is presented everywhere in its lack." 30 According to Badiou, set theory's "omnipresent" presentation of the void is nothing other than a declaration and affirmation of the death of God: "Ultimately, this halting point is the void, not the One. God is dead at the heart of presentation." 31 The empty set $\varnothing$ (i.e., "zero" or the "not," instead of the "one") is not just the "halting" or "stopping point" but also "the absolute initial point of being" from which all the other sets are unfolded. ${ }^{32}$ Thus, for Badiou, the void $\varnothing$ - the "not" - is both the initial point and the halting point of all being: to put it in Christian theological language, the void is the archè and telos of all things. ${ }^{33}$

If all things or all beings are sets, then there is, so to speak, set-ness in all things. ${ }^{34}$ The empty set-what Badiou calls the void-is something that formally predicates or indeed "sets" all things. ${ }^{35}$ As such, what we have here is in this regard something rather similar to the classical transcendentals: Common notions which are essential properties of all things. Moreover, as if echoing Thomas Aquinas's designation of "Being" as the most proper name of God, ${ }^{36}$ Badiou speaks of the void as "the proper name of Being." 37 Just as all creatures are said to bear a likeness to God's perfect oneness, truth and goodness in Aquinas's theological metaphysics, ${ }^{38}$ all beings are said to be marked by the void that is "included in everything" in Badiou's atheistic

\footnotetext{
29 Badiou (2005, p. 86).

30 Ibid.

31 Badiou (2004, pp. 116-117).

32 Badiou (2001, p. 25; 2005, p. 151; 2008, p. 83).

33 Cf. Revelation 21:6. For Badiou (2008, p. 84), the mathematical identification of zero as "the absolute initial point" provides modern thought with an immanent conception of the infinite which replaces God as the transcendent perfect ideal form of infinity: "Our passage through the ordinals (or the limits of our representation of them) arranges them according to an untotalisable sequence. This sequence 'starts' with 0 . It continues through the whole natural numbers $(1,2, \ldots, n, n+1, \ldots$, etc.), numbers whose form of being is composed of the void (under the forms $(0),(0,(0)),(0,(0),(0,(0))), \ldots$, etc.). It is continued by an infinite (re)commencement... From this point of view, the ordinals represent the modern scale of measurement (conforming to the two crucial decisions of modern thought) of natural multiplicity. They say that nothingness is a form of natural and numerable being, and that the infinite, far from being retained in the One of a God, is omnipresent in nature, and, beyond that, in every situation-being."

34 The notion of "set-ness" here refers to the "pure" set that does not contain anything, what Badiou calls the empty set or indeed "the void set" which is also simply "the void" itself - in set-theoretical terms it is simply " $\varnothing$ " or " \{\} ” (but not “ $\{\varnothing\}$," which would be one). Cf. Adrian Johnston's account of "a universal, empty, and contentless frame, a formal void" in a different but not unrelated context (Johnston 2008b, p. 12).

35 Badiou (2008, p. 83).

36 Aquinas (1980, vol. I, pp. 21-22 [=In I Sententiarum 8.1.1, 8.1.3]); cf. Aertsen (1996, p. 363).

37 Badiou (2005, p. 56).

38 See Aquinas (1980, vol. II, pp. 8-9 [=Summa Contra Gentiles I.28-30]).
} 
ontology. ${ }^{39}$ As opposed to all things reflecting the perfect oneness, truth, and goodness of God, Badiou's universal and omnipresent—and indeed, "transcendental"notion of the void is one which signifies the death and absence of God-that the divine is not. It is this void - this not and absence of God-that underlies all being. ${ }^{40}$ To paraphrase Psalm 19: All beings declare the death of God, all creatures proclaim his absence. $^{41}$

\subsection{Later Badiou: logical phenomenology}

For Badiou, the "omnipresent" declaration of the death of God by the void is formally an ontological thesis as opposed to a phenomenological one. ${ }^{42}$ Positioning himself against the phenomenological tradition, Badiou draws a peculiar distinction between ontology and phenomenology: Whereas ontology is mathematics, phenomenology is logic. ${ }^{43}$ As Badiou remarks in Logics of Worlds (his 2006 sequel to Being and Event): "just as being qua being is thought by mathematics (a position that is argued for throughout Being and Event), so appearing, or being-there-in-a-world, is thought by logic [in Logics of Worlds]." 44 As we can observe from Badiou's use of the plural for both "logic" and "world" in title of Logics of Worlds (and his use of the indefinite article in "being-there-in- $a$-world"-as opposed Heidegger's "being-in-the-world"), there is a deep commitment to the plurality or multiplicity of "worlds" (or "situations") in Badiou's project-something that is already developed in Being and Event. ${ }^{45}$

Following the central ontological thesis that "the One is not"- that there can be no oneness, unity or indeed "wholeness" in being - in Being and Event, Badiou fervently asserts that "there is no Whole" in Logics of Worlds:

\footnotetext{
39 Badiou (2005, pp. 86-87).

40 Although Badiou (2003a, p. 88) insists that his account of "the void is not that of consciousness: not Sartre's nothingness," Badiou (2012; 2009b) also often acknowledges Sartre's influence on his philosophical formation. For a discussion of how Sartre's notion of "nothingness" also functions ontologically as an atheistic transcendental which signifies that "God is not," see Leung (2020).

41 As opposed to "transcendental" conception of "truth" in medieval Scholastic ontology, Badiou (2001, p. 42) defines "truth" as "the real process of a fidelity to an event," something that is ontologically "indiscernible": "It is impossible for mathematical ontology to dispose of a concept of truth... The process of a truth thus entirely escapes ontology. In this respect, the Heideggerean thesis of an originary co-belonging of being and truth must be abandoned" (Badiou 2005, p. 355, see also pp. 327-343). It is beyond the scope and aims of this article to explicate Badiou's "process" or "procedural" conception of "truth" and his corresponding notion of "the event." For Badiou's latest account of "truth," see his recent third volume of Being and Event, entitled The Immanence of Truths (2018), in which Badiou's anti-theological agenda is clear: "s'il y a des vérités, et non la Vérité, c'est que l'absoluité d'une vérité ne signifie pas qu'une vérité est l'absolu. Car si elle l'était, nous devrions en conclure que seul l'absolu est vrai, en quoi nous reconnaîtrions sans difficulté le schème théologique" (p. 417).

42 Cf. Badiou (2005, p. 56): "in a situation there is no conceivable encounter with the void."

43 Badiou (2009a, p. 99).

44 Ibid., pp. 37-38.

45 See Badiou (2005, pp. 150-160).
} 
we will call universe the (empty) concept of a being of the Whole. We will call world a "complete" situation of being. Obviously, since we show that there is no universe, it belongs to the essence of the world that there are several worlds, since if there were only one it would be the universe. ${ }^{46}$

According to Badiou, the thesis that that "there is no universe" or "no Whole" is simply an extension of "the conceptual consequences of Russell's paradox." 47 In Badiou's reading, Russell's paradox (which famously shows that there can be no universal set of all sets that are not members of themselves) provides a "logical demonstration" that the existence of an absolute totality is inconsistent and self-contradictory - which, for Badiou, means that "a set of all sets cannot exist." 48

Before explicating the full implications of this assertion that there can be no "set of all sets," it is important to highlight why the "inexistence of the Whole" is integral to the formulation of Badiou's "logical phenomenology" in Logics of Worlds. According to Badiou, since "there is no Whole," there can be "no uniform procedure of identification and differentiation of what is." 49 For Badiou, given that there is no absolute totality—no "set of all sets" or "world of all worlds" (what he calls a "universe"), each world or situation has its own "logic" — what Badiou calls "transcendental indexing"- - which objectively describes, regulates and organises the appearances of things within those respective worlds. ${ }^{50}$ There are as many transcendental logics as there are worlds-hence the book title Logics of Worlds, which is why Badiou argues that there cannot be a "unified 'centre' of transcendental organisation, such as the Subject is for Kant." 51 As such, at the heart of Badiou's so-called "objective phenomenology" is a replacement of Kant's subjective account of the transcendental with a logical conception of the "transcendental" — as Badiou admits: "The [non-Kantian] concept of 'transcendental' is without doubt the most important operational concept in the whole of [his] theory of appearing." 52

Indeed, in his acknowledgement that he is "reprising the old word 'transcendental"" in Logics of Worlds, Badiou explicitly states that this "old word" is "detached from its constitutive and subjective value" in his objective phenomenology. ${ }^{53}$ What Badiou seeks to present with his "logical" formulation of the transcendental in Logics of Worlds is an "analytic of being-there [that] does not presuppose subject"-in other words, "a transcendental constitution (without subject)." ${ }^{54}$ Underlying Badiou's non-subjective "logical" account of the transcendental is ultimately a deeply anti-Kantian sentiment, as Badiou openly admits in Logics of Worlds:

\footnotetext{
46 Badiou (2009a, p. 102).

47 Ibid., p. 154. On Badiou's (and Agamben's) use of Russell's paradox, see Livingston (2009).

48 Badiou (2004, p. 178; 2009a, pp. 153-155).

49 Badiou (2009a, p. 112).

50 Badiou (2009a; 2014).

51 Badiou (2009a, p. 120).

52 Ibid., p. 596.

53 Ibid., p. 122.

54 Ibid., pp. 192, 102, cf. p. 571.
} 
Kant is the one author for whom I cannot feel any kinship... The critical machinery he set up has enduringly poisoned philosophy. ${ }^{55}$

However, despite his strong anti-Kantian rhetoric and his aspiration to develop a subject-less phenomenological account of the transcendental, Badiou's conception of "the transcendental" in phenomenological terms of appearance-as opposed to ontological terms of "Being" itself_-nonetheless still resembles Kant's critical idealist definition of transcendentality. ${ }^{56}$

At this point, it is worth revisiting an earlier interview Badiou held with Peter Hallward in 1997. Hallward asks: "Isn't it a kind of transcendental condition, an enabling condition of our existence, that we must always be specific to a situation?" To which Badiou responds:

I take it to be an ontological principle... I've no need to call it transcendental... I try to limit the use of the word "transcendental" to its Kantian meaning. "Transcendental" refers back to the subjective conditions of experience, and Kant never stops telling us that it is precisely not a law of being. It is a law of the unity of the phenomenon, not a law of being. If you want to extend the meaning of the word "transcendental" to the point that you call, in the end, transcendental the first or ultimate condition of thought in general, of existence in general, then at that point I'd agree: yes, it's transcendental. ${ }^{57}$

As we see from Logics of Worlds, Badiou inevitably moves away from understanding transcendentality in the Kantian meaning of the subjective conditions of experience, but nonetheless, like Kant, in Logics of Worlds Badiou still sees the "transcendental" as "a law of the unity of the phenomenon, [and] not a law of being." However, if we understand "transcendentality" not in a Kantian way, but in a preKantian if "classical" sense-in Badiou's words, not as "the first or ultimate condition of thought in general" but "of existence in general" - then it seems that Badiou would be happy to say that his mathematical account of being (and not appearance) is indeed "transcendental."

However, the "transcendental" attribution of the void to all things in Badiou's ontology is not a metaphysical ascription of essences or properties (such as oneness, truth, or goodness) to things that one finds in Scholastic ontology and its corresponding theological conception of the transcendentals. Badiou's ontology is deeply atheistic not just with its replacement of "the one" with the void or the not as a

\footnotetext{
55 Ibid., p. 535.

56 Moreover, not dissimilar to Badiou's understanding of the "one" as an operation in his set-theoretical ontology, for Kant, "an object is that in the concept of which the manifold of a given intuition is united" (Kant 1929, p. 156 [B137]). In fact, Kant's manifold of intuition is "united" as one object, can be translated into Badiou's terminology: The multiple of intuition is "counted-as-one" in the object. Yet, as we know, "the one is not" in Badiou's ontology of the multiple. The "one" is for Badiou (2005, p. 55) the result of the operation of "counting-as-one" (and not of the presentation of the multiple) - which is not dissimilar to Kant's transcendental operation of the synthetic unity in which "the manifold" becomes "united in one consciousness" (Kant 1929, pp. 156-157 [B138]). See Badiou (2004, pp. 135-138); cf. Johnston (2008a).

57 Badiou (2001, p. 135).
} 
transcendental notion that is convertible with "Being." Just as there can be no "set of all sets" according to his set-theoretical ontology, there is no God-like metaphysical structure such as an ideal "Form of all forms" or "value of values" by which we measure and evaluate things, nor is there a universal Platonic Good from which all things derived their being and goodness. ${ }^{58}$ For Badiou, while all things (sets) have "set-ness," there is no transcendent "set of all sets" in which these sets participate: All sets are all equally sets-no set is more perfect or less perfect as a set than any other set. $^{59}$

For Badiou, the inexistence of "a set of all sets" is one of the reasons why his set-theoretical ontology is "inessential": "A set, in Cantor's sense of the word, has no essence besides that of being a multiplicity; it is without external determination," precisely because "there cannot be a set of all sets" to act as an external or indeed transcendent metaphysical principle to determine or prescribe essences or properties to beings. ${ }^{60}$ It is for this reason that Badiou says that his "ontology attributes no other property to multiples than existence."61 Badiou's set-theoretical ontology "makes no claims concerning the nature of being... it has nothing to say about the qualities of identity of any concrete situation." ${ }^{2}$ While Badiou is not transcendental thinker in the Kantian sense, his "transcendental" ontology is a distinctively modern one insofar as it consciously avoids prescribing essences or natures to things. ${ }^{63}$ As we see in the following section, this "modern" attempt to develop an inessential transcendentality is something that is also-and perhaps more explicitly-found in the anti-essentialist ontology of one of Badiou's contemporaries: Giorgio Agamben.

\section{Giorgio Agamben}

\subsection{Earlier Agamben: "whatever" being}

In The Coming Community (1990), his first book that was translated into English (in 1993), Giorgio Agamben begins with a discussion of Scholastic transcendentals:

The coming being is whatever being. In the Scholastic enumeration of transcendentals (quodlibet ens est unum, verum, bonum seu perfectum-whatever entity is one, true, good, or perfect), the term that, remaining unthought in each, conditions the meaning of all the others is the adjective quodlibet. ${ }^{64}$

According to Agamben, the notion of quodlibet or "whatever" ("qualunque" in Agamben's Italian) is significant because the medieval transcendentals are all

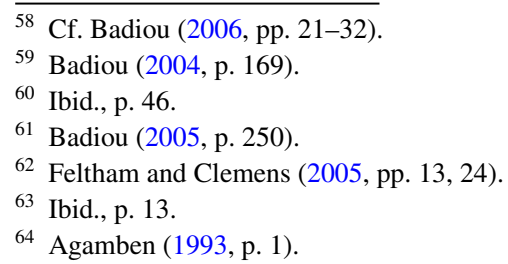


predicted with "whatever"- "whatever entity is one, true, good, or perfect": Quodlibetality is a condition that is more universal than the conventional Scholastic transcendentals such as oneness, goodness and truth. As such, Agamben argues that the adjective quodlibet is one which "conditions the meaning of all the others." If quodlibet or what Agamben calls the "whatever" is a notion which conditions all other transcendentals and is itself more universal than them, then it may be said to be "the transcendental of transcendentals" or what Agamben calls "the architranscendental" later in The Coming Community. ${ }^{65}$

However, despite the radical universality or commonality of "whatever" as an "architranscendental," Agamben insists that "whatever is the figure of pure singularity." 66 As Agamben notes:

The Whatever in question here relates to singularity not in its indifference with respect to a common property (to a concept, for example: being red, being French, being Muslim), but only in its being such as it is. Singularity is thus freed from the false dilemma that obliges knowledge to choose between the ineffability of the individual and the intelligibility of the universal. ${ }^{67}$

For Agamben, thinking the "whatever" as "the architranscendental" provides a framework which can ontologically account for the existence of an entity simply for "its being such as it is," without the "essentialist" need to defer to some supposedly "higher" or "transcendent" universal or common property: the individual thing is "not reclaimed for another class nor for the simple generic absence of any belonging, but for its being-such."68

In traditional essentialist metaphysics, a particular red entity would be understood (or predicated) as being "red" by belonging to the set of "red things" —or in Platonic terms, by participation in the universal idea of "redness." The particular red entity can never be as perfectly or properly red as the universal ideal of "redness": the particular is always hierarchically understood as being subordinate to the universal, always less "proper" and less "perfect" than the universal. It is against such a hierarchical outlook of traditional metaphysics that Agamben develops what may be called a "flat ontology" of equality by positing "whatever being" as a transcendental or indeed "the architranscendental." that is found equally in all things - that no being is more or less "whatever" than any other, each individual thing may be understood and affirmed in its "singularity" (as opposed to its "particularity," which would always be understood in some hierarchical relation to "the universal"). ${ }^{70}$ Each and every thing equally "matters" for what and how they are in themselves, and not by virtue of their relation to "the universal"

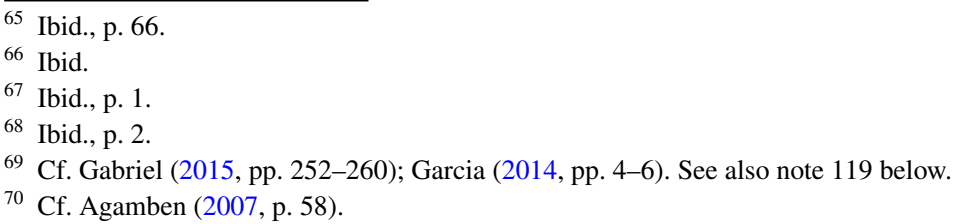


or "the proper"—as Agamben puts it: "Quodlibet ens is not 'being, it does not matter which', but rather 'being such that it always matters'., 71

Not unlike the "transcendental" role played by the empty set or the void in Badiou's mathematical ontology, ${ }^{72}$ Agamben's transcendental "whatever" is also a structure of "emptiness": "Whatever adds to singularity only an emptiness... Whatever is a singularity plus an empty space." "73 For Agamben, the "whatever" is "an emptiness" because it is a notion that can affirm the commonality between things without (re-)establishing any kind of hierarchical metaphysical essentialism. ${ }^{74}$ Drawing on the ontology of Duns Scotus, Agamben writes:

Duns Scotus [teaches] that there is no difference of essence between common nature and haecceity. This means that the idea and common nature do not constitute the essence of singularity, that singularity is, in this sense, absolutely inessential. $^{75}$

Echoing Deleuze's genealogy of the univocity of being ${ }^{76}$ Agamben places Spinoza in the same philosophical lineage of "inessential" ontology as Duns Scotus:

Nothing is more instructive in this regard than the way Spinoza conceives of the common... what is common cannot in any case constitute the essence of the single case. Decisive here is the idea of an inessential commonality, a solidarity that in no way concerns an essence... Whatever is constituted not by the indifference of common nature with respect to singularities, but by the indifference of the common and the proper, of the genus and the species, of the essential and the accidental. ${ }^{77}$

At the heart of Agamben's formulation of the quodlibet as "the architranscendental" is an account of "inessential commonality," his theory of the "whatever" is not only a re-conception of the medieval Scholastic transcendentals but also a re-conception

\footnotetext{
71 Agamben (1993, p. 1).

72 Moreover, not unlike Badiou's attribution of a paradoxical "omnipresence in its lack" to the void, Agamben attributes a paradoxical "impotent omnivalence" to the "whatever" (ibid., p. 10).

73 Ibid., p. 67, emphasis added. This sense of "transcendental emptiness" is also found in Agamben's review of Jean-Claude Milner's work on linguistics published in 1990 (the same year as the original publication of The Coming Community). In this review, Agamben speaks of "pure existence" as "a singularity without real properties," something that is "without any properties other than transcendental ones"-because "transcendental predicates (unum, verum, bonum, etc.) [belong] to all predication without thereby adding any real property to it" (Agamben 1999, pp. 68, 71). As such, Agamben (1999, p. 73) concludes, "the transcendentia of medieval logic" is fundamentally "empty of real content." Cf. Agamben (1991, pp. 21-22): "[Transcendentals] accompany (concomitantur) every entity without adding anything real to it... the speculative medieval grammars attempted to specify the status of the pronoun with respect to the transcendentia. While these terms denote the object as an object in its universality, the pronoun - they claim —indicates, instead, an indeterminate essence, a pure being... [something that is] "null and void'."

74 Cf. Kishik (2012, pp. 18-19, 23-24, 88-89).

75 Agamben (1993, p. 18).

76 Cf. Agamben (2009, pp. 220-239).

77 Agamben (1993, pp. 18-19), Agamben's original emphasis.
} 
of commonality that frees the individual from (what Agamben sees as) the "essentialist" trappings of traditional metaphysics.

To the extent that a "whatever singularity" is "a being that is its mode of being" which cannot be accounted for "in terms of the division that dominates Western ontology, either an essence or an existence,"78 Agamben's "whatever" is an ontological figure of "pure Being": The being that the "whatever" is simply is its mode of being, what it is (its essence) coincides with its way of being (its existence) — as Agamben puts it in Heidegger's formulation of Dasein, its "essence lies in its existence." 79 Insofar as there is a coincidence-or indeed "indifference"-of essence and existence in Agamben's "whatever," this ontological figure of "pure Being" may be compared to the classical theological conception of God as "Being itself" (ipsum esse), ${ }^{80}$ as notably expressed in the aforementioned designation of "He who is" (qui est) as the "most proper name" of God. ${ }^{81}$ As Agamben summarises this traditional metaphysical conception in his words: "[God's] essence and existence coincide, the existence of God and his essence are one sole and identical thing." 82 In light of these parallels between the ontological figures of Agamben's "whatever" and God as "He who is," Claire Colebrook and Jason Maxwell describe Agamben's project as "a way of reversing the theology of essence and existence":

God, traditionally, is pure existence and is not subject to being an instance of any kind, nor of having a specifiable identity. God's essence is his existence, nothing more. For Agamben, that way of thinking about God as pure existence not limited or marked out by being of a certain kind is a better way of thinking about all existence. ${ }^{83}$

What we find in Agamben's inessential ontology of the "whatever" is thus not just an equal and "indifferent" affirmation of the worth and value of all beings, ${ }^{84}$ but moreover a profanation of "Being itself": "Being" is no longer something that belongs "properly" to the divine and only "improperly" to other (created) beings who derive their existence from God who alone is "pure Being" or indeed "Being

\footnotetext{
78 Ibid., p. 28.

79 Ibid., p. 98; see also Agamben (1998, pp. 182, 188; 2015, pp. 133, 174-175).

80 Aquinas (1980, vol. II, pp. 6-7, 10 [=Summa Contra Gentiles I.22, I.38.5]).

81 Aquinas (1980, vol. I, pp. 21-22 [=In I Sententiarum 8.1.1, 8.1.3]). Cf. Agamben (2010, pp. 52-53): "The connection of the theological theme of the name of God with the philosophical one of absolute being, in which essence and existence coincide, is definitively carried out in Catholic theology... Thomas Aquinas, taking up again the thesis of Maimonides on the name qui est, can write that it "names a being that is absolute and undetermined by anything added" (commenting on Aquinas, In I Sententiarum 8.1.1).

82 Agamben (2010, p. 56). See also Agamben (2011, p. 25).

${ }^{83}$ Colebrook and Maxwell (2016, pp. 98, 119, emphasis added), commenting on Agamben (1993, pp. 10, 15, 17). See also Kishik (2012, pp. 84-85). In Colebrook and Maxwell's reading, Agamben's reversal of the theology of essence and existence very much parallels Badiou's postulation of the multiple over against the One: "traditionally, God is the only pure existence... However, if we think of all being as just being the existence that it is - a 'thisness' that is not the expression of a prior being or form - then existence becomes multiple" (Colebrook and Maxwell 2016, p. 119, emphasis added).

84 Agamben (1993, pp. 18-19).
} 
itself." 85 Instead, by positing an architranscendental indifference of the common and the proper or indeed of essence and existence to all beings, Agamben argues that "this world as it is is God, and that redemption lies in seeing everything as it is in its irreparable beauty." $" 86$

Agamben's indifferent and equal attribution of "pure Being" to all things through the transcendental notion of "whatever"-as well as his "profane" assertions that "the world is God"-may give the impression that Agamben professes some version of pantheism, ${ }^{87}$ however, what Agamben highlights in his ontology is "not a pantheistic awareness of the world's sacredness but rather of its 'irreparably profane character'." 88 As we see in the following section on Agamben's engagement with Spinoza in his later work, what we find in Agamben's work is not a pantheism which simply ascribes divinity to all things, but rather an ontology which renders all existing things as "modes." ${ }^{\circ 9}$ Like his earlier ontology of whatever being, Agamben's later work is also consciously anti-essentialist: Instead of a (pan)theistic view of entities in terms of some divine essence, by understanding beings in terms of "mode" — which he defines as an "inessential adjunct" that is "totally deprived of an essence"-what we find in Agamben's later "modal" ontology is yet another quasiclassical notion of a transcendental or even an "architranscendental" which affirms and upholds an "inessential commonality" between beings that "in no way concerns an essence." 90

\subsection{Later Agamben:"modal" being}

In The Use of Bodies (2015), the final book of his grand Homo Sacer project published some 25 years after The Coming Community, Agamben draws an explicit connection between the medieval Scholastic transcendentals and the ontological notion of "mode":

Being does not preexist the modes but constitutes itself in being modified, is nothing other than its modifications... [This is] the only sense of the doctrine of the transcendentals: the being that is always already its modifications; it demands to be unum, verum, bonum seu perfectum. ${ }^{91}$

\footnotetext{
85 Ibid., p. 15.

86 Colebrook and Maxwell (2016, p. 42), citing Agamben (1993, p. 90).

87 See Agamben (1993, p. 90): "The world-insofar as it is absolutely, irreparably profane-is God." See also Dickinson (2014, pp. 66, 78).

88 Baker (2019, p. 20), citing Agamben (1993, p. 90).

89 Like his early account of "whatever" being, in his later work Agamben also speaks of the concept of "mode" as one which "seeks to think the coincidence or indifference of essence and existence" (Agamben 2015, p. 161, cf. p. 155).

90 Ibid., pp. 155, 157; Agamben (1993, pp. 18-19).

91 Agamben (2015, p. 170).
} 
According to Agamben, the classical transcendentals of oneness, truth, goodness or perfection are "modes" in which Being always already modifies itself. ${ }^{92}$ Indeed, the very notion of "mode" is central to the Scholastic formulation of transcendentality, according to which classical transcendentals such as oneness, truth and goodness are nothing other than expressions of "the general mode consequent on every being" (modus generalis consequens omne ens). ${ }^{93}$ As such, if all the transcendentals-and, by extension, all beings - can be predicated with the notion of "mode," then "mode" is in a sense yet another "most common notion" for Agamben, not unlike the "architranscendentality" of "whatever."

However, Agamben's main inspiration for the ontology of "mode" he develops in The Use of Bodies does not come from the medieval Scholastics, but rather from Spinoza. To quote The Use of Bodies at some length:

Spinoza's radical ontological thesis is well known: "Nothing exists except substance and modes." It has been stated that Spinoza's novelty does not consist in the definition of substance but in that of modes... [Whereas] the Scholastic tradition distinguished between essence and existence and between common nature and individual supposition and made use of the concept of mode to think these differences... the substance/modes relationship is posed for him in an entirely different way from the way that Scholasticism had thought the passage from common nature to the individual supposition. ${ }^{94}$

According to Agamben, we would fail to understand and appreciate Spinoza "as long as we are constrained to think it in terms of the concepts of traditional ontology." 95 For Agamben, the relation between Spinoza's mode and substance is be understood not in terms of "what," but in terms of "how": Spinoza's mode "has a constitutively adverbial nature, it expresses not "what' but 'how' being is." 96 As opposed to "the primacy of essence" which characterises Scholasticism and traditional ontology, Agamben finds in Spinoza's work a "modal ontology"- an ontology not of "the what" (essence), but of "the how" (mode). ${ }^{97}$

For Agamben, it is only when Spinoza is understood not as an "essentialist" but as a "modal" ontologist that one can truly appreciate the radicality of Spinoza's controversial conception of God or substance. In Agamben's reading, Spinoza is no simple pantheist who merely asserts and believes that nature is somehow "divine." As Agamben argues:

\footnotetext{
92 Compare this to Agamben's (2009, pp. 65-66) other (re-)interpretation of the Scholastic transcendentals in The Signatures of All Things: Not dissimilar to how being coincides with its mode in his modal ontology in The Use of Bodies, in The Signatures of All Things Agamben argues that "being and its passions coincide" if one understand the medieval transcendentals as "signatures" or "passions of being."

93 Aquinas (1980, vol. III, p. 1 [= De Veritate 1.1]).

94 Agamben (2015, p. 160).

95 Ibid.

96 Ibid., p. 164.

97 Ibid., pp. 151, 231.
} 
The Spinozan syntagma Deus sive nature does not mean "God=nature": the sive expresses the modalization, which is to say, the neutralization and disappearance of identity as much as difference. What is divine is not being in itself but its sive, its always already modifying itself and "naturing itself"-being born-in the modes. ${ }^{98}$

God or substance does not have being "in itself" but only in modification; God (or Nature) only is "adverbially" in the process - in the how - of modifying itself. The novelty of Spinoza's "modal ontology" lies in the fact that the mode exists as a how instead of a what: a mode does not have being by virtue of "belonging to" the one common substance that is God, rather, a mode simply is as a mode itself. As Agamben notes in a statement found both in The Coming Community and The Use of Bodies: it is "not a being that is in this or that mode, but a being that is its mode of being." 99

For while all things may be "transcendentally" said to be modes in Agamben's ontology, this "transcendental" predication is an "inessential" one which does not prescribe any identity or quality to the modes. Parallel to how there is no transcendent "set of all sets" which measure the "set-ness" of things in Badiou's set-theoretical ontology, there is no "mode of all modes" or transcendent ideal form of "the Mode" in Agamben's modal ontology of the how. ${ }^{100}$ As opposed to defining things in terms of essences or what they are, Agamben's neo-Spinozist ontology of "mode" does not seek to "fix" or "schematise" beings into inert identities:

Spinozan pantheism, if it is a question of pantheism, is not an inert identity (substance $=$ mode) but a process in which God affects, modifies, and expresses Godself... Mode expresses this "rhythmic" and not "schematic" nature of being: being is a flux, and substance "modulates" itself and beats out its rhythm-it does not fix and schematize itself-in the modes. ${ }^{101}$

As such, like Badiou's ontology of "set," Agamben's ontology of "mode" is also deeply "inessential" or even anti-essentialist: Instead of hierarchical deprivations or imitations of some transcendent divine ideal essence, all things simply exist equally as "modes". 102

With all this discussion of Spinoza's God as well as his various works which draw heavily on the Christian theological tradition, unlike Badiou's militantly atheistic ontology, a latent figure of the divine may be said to exist in Agamben's ontology. ${ }^{103}$

\footnotetext{
98 Ibid., p. 164.

99 Agamben (1993, p. 28; 2015, p. 224).

100 This inessential or even anti-essentialist shift from "the what" to "the how" in Agamben's modal ontology may be compared to Badiou's focus on "the how" of presentation-what Badiou calls "the presentation of presentation"-in his ontology, which concerns "what presents itself [which] is essentially multiple" as opposed to "what presents itself [which] essentially is one" (Badiou 2005, pp. 27, 23).

101 Agamben (2015, pp. 165, 173).

102 Cf. ibid., p. 167: "The whole problem of the relation between essence and existence, between being and relative being appears in a new light if it is placed in the context of a modal ontology. Essence cannot be without the relative nor being without the entity."

103 Cf. Badiou's (2009a, pp. 558-559) description of Agamben as a "Franciscan of ontology" whose "latent Christianity generates a kind of modern poetics."
} 
However, in Agamben's neo-Spinozist modal ontology, there is not a "God" who operates as a transcendent principle from which all things are derived: For Agamben, the divine is not some sovereign figure by which we measure the essence or nature-be it oneness, truth, or goodness - of things. ${ }^{104}$ Even if there was a figure of the divine in Agamben's ontology, it would be nothing more than an empty figure, what Agamben refers to as "the empty throne" or indeed "the void." ${ }^{105}$ As such, even though Agamben does not explicitly affirm the death of God like Badiou does, what we find in Agamben's account of the divine is a profanation or indeed "a revision of theology that perhaps appears to some to amount to a practical form of atheism." 106 As Colby Dickinson notes, Agamben's ontology "leaves open the chance that God still does exist": it is an ontology which "may yet harbor a silent transcendence along its borders, forever inaccessible yet grounding everything that is said, one that exists, if at all, as if it did not really matter at all.",107

Indeed, while we find an ongoing engagement with the Scholastic formulation of the transcendentals from his early account of "whatever" in The Coming Community to his later ontology of "mode" in The Use of Bodies, underlying Agamben's treatment of these ideas is an endeavor to profane the structures of thought which bear any resemblance to theological conceptions of the divine-including the classical transcendentals. ${ }^{108}$ For Agamben, "to profane" is to render something "free of sacred names" and "put them to a new use." 109 What Agamben does—or indeed profanes-with regards to the classical transcendentals (which, as noted, are correlated with the divine names in traditional metaphysics) is to "free" transcendentality of its theological or divine connotations and put it to a new use: To indeed use the classical structure of transcendentality as a (new) way of profaning the theological structures of thought which underlie ontology. ${ }^{110}$ With this profanation of the transcendentals, beings are no longer conceived as pointing to some transcendent

\footnotetext{
104 As opposed to Agamben's “inessential” reading of Spinoza, in Badiou's (2005, pp. 112-120) own reading of Spinoza, to say that a thing is a mode of God is to say that "a thing necessarily belongs to [the] 'infinities in infinite modes' (infinita infinitis modis) which 'follow' divine nature" (ibid., p. 113).

105 See Agamben (2011, pp. xiii, 211, 242-248, especially p. 245). See also note 108 below.

106 Dickinson (2014, p. 77).

107 Ibid., pp. 77-78.

108 According to Agamben, the traditional theological categories of metaphysical transcendence reinforce a sacralization — and in turn, a legitimation — of political power (see Agamben 2011). The desacralization or indeed profanation of the sacred or theological paradigm which underlies governmental categories is thus a "political operation" to neutralize and deactivate structures of power and oppression (Agamben 2007, p. 77).

109 Agamben (2007, pp. 73, 87).

110 Indeed, for Agamben (2007, pp. 86-87), "to make new use possible" is "to transform them into pure means"-into "a means without an end." In the case of the transcendentals, it may be simply said that under Agamben's profane rendition, the transcendental properties that are universally shared by all things no longer point to some transcendent telos (the divine perfections), but simply exist as "pure means" that are "without ends." Agamben's "profane use" of the transcendentals may be compared with his "profane
} 
telos or divine source. While such a separation of "Being" from essential determinations or indeed from the classical transcendentals is by no means new in the history of philosophy, unlike previous philosophical efforts which replace the divine with some transcendental human subject, at the heart of Agamben's - as well as Badiou's - ontology is an atheistic yet (quasi-)classical conception of transcendentality. As in Badiou's set-theoretical ontology, we find in Agamben's ontology a quasiclassical transcendental notion of "the void" or "the not" which replaces the divine names (such as the one, the true, the good) as a universal predicate of all being-in Agamben's words: it points us to "the Nothing of all things." 111

\section{Conclusion}

Drawing on the Latin meaning of the adverb modo as "a short time ago, just now, recently," Agamben argues that there is an intrinsic etymological connection between the notions of "mode" and "modern" in The Use of Bodies:

the temporal form of mode is neither the past nor the present nor even less the future: it is the modern... the term modernus always implies a tension with regard to the past, as if the present could grasp and define itself only in a gap with respect to itself. That is to say, the modern is intimately historical and archaic, because it has need of the ancient to refer and, at the same time, to oppose to itself. ${ }^{112}$

Indeed, this "modern" sentiment is something we could find in Kant's juxtaposition of his own subjective account of the transcendental as a "modern" conception that stands in opposition to that of the "transcendental philosophy of the ancients": To use Agamben's formulation, Kant's project "has need of [the transcendental philosophy of] the ancient to refer and, at the same time, to oppose to itself.,"113

\footnotetext{
Footnote 110 (continued)

use" of St. Paul's notion of "as not" (hōs $m \bar{e})$ in 1 Corinthian 7:29-31 across his various works (Agamben 2005, pp. 23-28; 2011, p. 248; 2015, pp. 56-57, 274). While Badiou (2003b, pp. 46-47) also highlights St. Paul's notion of "not" $(m \bar{e})$ in 1 Corinthians 1:28 as one of "ontological subversion" in his book on St. Paul, both Badiou (2009a, pp. 558-559) and Agamben (2005, pp. 51-52) are keen to distinguish themselves from each other's work on St. Paul.

111 Agamben (1999, p. 46): "Contemporary thought has approached a limit beyond which a new epochal-religious unveiling of the word no longer seems possible... no new figure of the divine, no new historical destiny can lift itself out of language... If God was the name of language, 'God is dead' can only mean that there is no longer a name for language... Nihilism experiences this very abandonment of the word by God. But it interprets the extreme revelation of language in the sense that there is nothing to reveal, that the truth of language is that it unveils the Nothing of all things... the Nothing as the final veil, the final name of language." Cf. ibid., p. 252: "Cabalists and mystics... stated that the Nothing from which all creation proceeds is God himself. Divine Being (or rather hyper-Being) is the Nothing of beings."

112 Agamben (2015, p. 173).

113 Cf. Aertsen (2012, p. 14): "Kant emphasizes the fundamental discontinuity with Scholastic thought, but the fact remains that it is an opposition to a 'transcendental philosophy'."
} 
Aside from Kant, Agamben's genealogical remarks on the etymological origins of "the modern" can also be applied to Agamben himself. As Agamben further notes in The Use of Bodies:

The person who is properly modern, in this sense, is not the one who opposes the ancient so much as the one who understands that only when something "has done its time" does it become truly urgent and actual. ${ }^{114}$

Just as modern philosophy (as perhaps best represented by Kant) deems that the classical theory of transcendentals "has done its time," the person "who is properly modern" (as perhaps represented by Agamben and Badiou) is not someone who opposes classical or indeed "ancient" approaches to ontology, but one who understands that an ontological approach such as that of "the transcendental philosophy of the ancients" is all the more "truly urgent and actual."

But while we can find ontological structures which have certain resemblances to the medieval Scholastic transcendentals in Badiou's and Agamben's ambitious and provocative projects, as we see in their firm stance against metaphysical essentialism, their non-Kantian approaches to ontology is by no means a simply retrieval of some "transcendental philosophy of the ancients." Instead of a transcendent figure of God, what we find in Badiou's and Agamben's quasi-classical conceptions of transcendentality is an ontological figure of "emptiness," a figure of the "not" or indeed the "void" - as if there is an "empty throne" (to use Agamben's phrase) at the heart of contemporary ontology that is left vacant after the death of God. As such, to the extent that this "empty" figure of the inexistent divine may be regarded as a transcendental notion which is universally marked upon all beings in their ontologies, we may say that Badiou and Agamben are indeed "properly modern" thinkers-or as Badiou describes his own work, "not only modern, but perhaps even "more-than-modern'."115 Like how the modern "has need of the ancient to refer and, at the same time, to oppose to itself," the "more-than-modern" ontologies of Badiou and Agamben have need of the divine to refer to and, at the same time, to oppose to themselves. ${ }^{116}$

But as opposed to the modern displacement of the divine with the human subject as the "transcendental" principle by which all things are measured and evaluatedas one finds in Kant's subjective re-definition of the "transcendental," Badiou and Agamben do not simply seek to occupy the empty place of the dead God with the human subject or some other transcendental principle. As we have seen in this article, the emptying or voiding — or indeed "death" - of the divine as an overarching formal principle is affirmed and embraced by Badiou and Agamben by ontologising

\footnotetext{
114 Agamben (2015, p. 173).

115 Badiou (2004, p. xv). Badiou here further adds that "the adjective 'postmodern' has been evacuated of all content." While Agamben could arguably be regarded as a "postmodern" thinker in light of his hostility towards the traditional metaphysical notions of "substance" and "subjectivity," to the extent that his philosophical project pertains to what Badiou (2004, p. xv) calls "the classical problematic" of the question of "being," then perhaps Agamben could be described as a "more-than-modern" philosopher alongside Badiou.

116 Agamben (2015, p. 173).
} 
or indeed transcendentalising the empty place left void by the dead God - the not of God-into a constitutive principle which structures their "more-than-modern" outlooks: At the heart of Badiou's and Agamben's ontologies is a transcendental formalisation of atheism or indeed an atheistic profanation of classical transcendentality. ${ }^{117}$

By considering Badiou's and Agamben's ontologies through the perspective of classical transcendentality, we can come to a better understanding of the common traits that underly contemporary continental philosophy as well as the trajectory of post-Kantian philosophy in the history of western metaphysics. By replacing the one, the true, the good-or even the divine-with "empty" notions such as "the void" or "the not" as transcendental principles which ungird the structure of being, Badiou's and Agamben's "classical" endeavours to "think Being" not only mark a clear break from Kant's critical injunction on metaphysics, their conscious "atheological" efforts to develop systematic ontologies which do not prescribe or impose any essence onto individual beings moreover also differ from the theological metaphysics of the mediaeval Scholastics and corresponding essentialist schemas of the hierarchy of being. To use Agamben's formulation of "the modern" again, Badiou's and Agamben's projects are "more-than-modern" endeavours which have need of previous accounts of transcendental philosophy - whether classical or Kantianto refer to and, at the same time, to oppose to itself. ${ }^{118}$ Badiou's and Agamben's "transcendental philosophy of the atheists" may thus be understood as one which supersedes both the classical and modern conceptions of transcendental philosophy, a new kind of transcendental philosophy that is not only key to the recent revival of metaphysical theorisation in contemporary philosophy but, perhaps, even part of the beginning of a new chapter in the history of western metaphysics. ${ }^{119}$

Open Access This article is licensed under a Creative Commons Attribution 4.0 International License, which permits use, sharing, adaptation, distribution and reproduction in any medium or format, as long as you give appropriate credit to the original author(s) and the source, provide a link to the Creative Commons licence, and indicate if changes were made. The images or other third party material in this article are included in the article's Creative Commons licence, unless indicated otherwise in a credit line to the material. If material is not included in the article's Creative Commons licence and your intended use is

\footnotetext{
117 Cf. Badiou (2007, pp. 165-178); Agamben (2007, especially pp. 73-92). Agamben's distinction between "profanation" and "secularisation" is helpful here to highlight how Badiou's and Agamben's "more-than-modern" approach differs from what Badiou (2007, pp. 169-172) describes as Sartre's "radical humanism" in which the human subject occupies the place left empty by (the dead) God. Whereas secularisation "leaves intact the forces it deals with by simply moving them from one place to another"such as the "radical humanist" replacement of the ontological figure of God with the human subjectthereby leaving the theological structure of transcendence in place, Agamben's (and Badiou's) profanation "neutralizes what it profanes" and altogether deactivate the crypto-theological character of ontology (Agamben 2007, p. 77).

118 Agamben (2015, p. 173).

119 Cf. Adrian Johnston's characterization of the contemporary pursuit of an "One-less ontology" or indeed a "Godless ontology" as one that is "completely secularized and genuinely atheistic" (Johnston 2013, pp. xv, 5). Indeed, aside from Badiou and Agamben, "empty transcendental" notions similar to Badiou's "empty set" and Agamben's "whatever" can also be found in the recent systematic ontologies of contemporary philosophers such as Markus Gabriel's (2015) “field of sense” and Tristan Garcia's (2014) "no-matter-what."
} 
not permitted by statutory regulation or exceeds the permitted use, you will need to obtain permission directly from the copyright holder. To view a copy of this licence, visit http://creativecommons.org/licen ses/by/4.0/.

\section{References}

Aertsen, Jan A. 1996. Medieval Philosophy and the Transcendentals: The Case of Thomas Aquinas. Leiden: Brill.

Aertsen, Jan A. 2012. Medieval Philosophy as Transcendental Thought: From Philip the Chancellor to Francisco Suárez. Leiden: Brill.

Agamben, Giorgio. 1991. Language and Death: The Place of Negativity. Trans. Karen E. Pinkus with Michael Hardt. Minneapolis, MN: University of Minnesota Press.

Agamben, Giorgio. 1993. The Coming Community. Trans. Michael Hardt. Minneapolis, MN: University of Minnesota Press.

Agamben, Giorgio. 1998. Homo Sacer: Sovereign Power and Bare Life. Trans. Daniel Heller-Roazen. Stanford, CA: Stanford University Press.

Agamben, Giorgio. 1999. Potentialities: Collected Essays in Philosophy. Trans. and Edited by Daniel Heller-Roazen. Stanford, CA: Stanford University Press.

Agamben, Giorgio. 2005. The Time that Remains: A Commentary on the Letter to the Romans. Trans. Patricia Dailey. Stanford, CA: Stanford University Press.

Agamben, Giorgio. 2009. The Signature of All Things: On Method. Trans. Luca D'Isanto and Kevin Attell. New York: Zone Books.

Agamben, Giorgio. 2007. Profanations. Trans. Jeff Fort. New York: Zone Books.

Agamben, Giorgio. 2010. The Sacrament of Language: An Archaeology of the Oath. Trans. Adam Kotsko. Stanford, CA: Stanford University Press.

Agamben, Giorgio. 2011. The Kingdom and the Glory: For a Theological Genealogy of Economy and Government. Trans. Lorenzo Chiesa. Stanford, CA: Stanford University Press.

Agamben, Giogrio, 2013. Opus Dei: An Archaeology of Duty. Trans. Adam Kotsko. Stanford, CA: Stanford University Press.

Agamben, Giorgio. 2015. The Use of Bodies. Trans. Adam Kotsko. Stanford, CA: Stanford University Press.

Aquinas, Thomas. 1980. S. Thomae Aquinatis Opera Omnia. Edited by Robertus Busa. Stuttgart: Frommann-Holzboog.

Badiou, Alain. 2000: Deleuze: The Clamor of Being. Trans. Louise Burchill. Minneapolis, MN: University of Minnesota Press.

Badiou, Alain. 2001. Ethics: An Essay on the Understanding of Evil. Trans. Peter Hallward. London: Verso.

Badiou, Alain. 2003a. Philosophy and Psychoanalysis. In Infinite Thought: Truth and the Return to Philosophy, ed. Oliver Feltham and Justin Clemens, 79-90. London: Continuum.

Badiou, Alain. 2003b. Saint Paul: The Foundation of Universalism. Trans. Ray Brassier. Stanford, CA: Stanford University Press.

Badiou, Alain. 2004. Theoretical Writings. Trans. Ray Brassier and Alberto Toscano. London: Continuum.

Badiou, Alain. 2005. Being and Event. Trans. Oliver Feltham. London: Continuum.

Badiou, Alain. 2006. Briefings on Existence: A Short Treatise on Transitory Ontology. Trans. Norman Madarasz. Albany, NY: State University of New York Press.

Badiou, Alain. 2007. The Century. Trans. Alberto Toscano. Cambridge: Polity.

Badiou, Alain. 2008. Number and Numbers. Trans. Robin MacKay. Cambridge: Polity.

Badiou, Alain. 2009a. Logics of Worlds: Being and Event, 2. Trans. Bruno Bosteels. London: Continuum.

Badiou, Alain. 2009b. Jean-Paul Sartre (1905-1980). In Pocket Pantheon: Figures of Postwar Philosophy, 14-35. Trans. David Macey. London: Verso.

Badiou, Alain. 2012. Commitment, Detachment, Fidelity. In The Adventure of French Philosophy, ed. Bruno Bosteels, 27-37. London: Verso.

Badiou, Alain. 2014. Mathematics of the Transcendental. Trans. A.J. Bartlett and Alex Ling. London: Bloomsbury. 
Badiou, Alain. 2018. L'immanence des vérités: l'être et l'événement, 3. Paris: Fayard.

Baker, Gideon. 2019. Critique, Use and World in Giorgio Agamben's Genealogy of Government. Global Society 33 (1): 12-25.

Brophy, Susan D. 2019. Freedom without Being: Kant's Corrective as the Philosophical Crux of Agamben's “Homo Sacer" Series. European Journal of Political Theory 18 (2): 195-215.

Colebrook, Claire, and Jason Maxwell. 2016. Agamben. Cambridge: Polity.

Dickinson, Colby. 2014. The Profanation of Revelation: On Language and Immanence in the Work of Giorgio Agamben. Angelaki 19 (1): 63-81.

Feltham, Oliver, and Justin Clemens. 2003. An Introduction to Alain Badiou's Philosophy. In Infinite Thought: Truth and the Return to Philosophy, ed. Oliver Feltham and Justin Clemens, 1-28. London: Continuum.

Fraenkel, Abraham A., Yehoshua Bar-Hillel, and Azriel Levy. 1973. Foundations of Set Theory, 2nd ed. Amsterdam: North-Holland.

Gabriel, Markus. 2015. Fields of Sense: A New Realist Ontology. Edinburgh: Edinburgh University Press.

Garcia, Tristan. 2014. Form and Object: A Treatise on Things. Trans. Mark Allan Ohm and Jon Cogburn. Edinburgh: Edinburgh University Press.

Honnefelder, Ludger. 2003. Metaphysics as a Discipline: From the Transcendental Philosophy of the Ancients to Kant's Notion of Transcendental Philosophy. In The Medieval Heritage in Early Modern Metaphysics and Modal Theory, ed. R.L. Friedman and L.O. Nielsen, 53-74. Dordrecht: Springer.

Johnston, Adrian. 2008a. Phantom of Consistency: Alain Badiou and Kantian Transcendental Idealism. Continental Philosophy Review 41 (3): 345-366.

Johnston, Adrian. 2008b. Žižek's Ontology: A Transcendental Materialist Theory of Subjectivity. Evanston, IL: Northwestern University Press.

Johnston, Adrian. 2013. Prolegomena to Any Future Materialism: The Outcome of Contemporary French Philosophy. Evanston, IL: Northwestern University Press.

Kant, Immaneul. 1929. Critique of Pure Reason. Trans. Norman Kemp Smith. London: Macmillan.

Kishik, David. 2012. The Power of Life: Agamben and the Coming Politics. Stanford, CA: Stanford University Press.

Leung, King-Ho. 2020. Transcendentality and Nothingness in Sartre's Atheistic Ontology. Philosophy 95 (4): 471-495.

Livingston, Paul M. 2009. Agamben, Badiou, and Russell. Continental Philosophy Review 42 (3): 297-325.

Milbank, John. 2014. Beyond Secular Order: The Representation of Being and the Representation of the People. Oxford: Wiley-Blackwell.

Nirenberg, Ricardo, and David Nirenberg. 2011. Badiou's Number: A Critique of Mathematics as Ontology. Critical Inquiry 37 (4): 583-614.

Publisher's Note Springer Nature remains neutral with regard to jurisdictional claims in published maps and institutional affiliations. 